The Journal of Animal \& Plant Sciences, 31(2): 2021, Page: 409-415

ISSN (print): 1018-7081; ISSN (online): 2309-8694

\title{
GENETIC AND MORPHOLOGICAL CHARACTERIZATION OF LEBANESE MOUNTAIN LOCAL GOAT POPULATION
}

\author{
T. Mira ${ }^{1 *}$, Abi-Rizk Alain ${ }^{1}$, A. Charbel ${ }^{1}$ and A. S. Saab ${ }^{1}$ \\ ${ }^{1}$ Faculty of Agricultural and Food Sciences, Holy Spirit University of Kaslik, P.O. Box 446, Jounieh, Lebanon. \\ *Corresponding author: myratabet@gmail.com
}

\begin{abstract}
Lebanese mountain Baladi goats are endemic to Lebanon. However, few available genetic data on Baladi population is available. Information based on morphological and biochemical markers exists but yet remains imprecise. The aim of this study is to characterize the morphological and genetic traits of the Lebanese mountain Baladi population. The experiment was carried out in two different regions: Deir El Ahmar(1450m) and Boksmaya (400m). A total of 47 does, aging between 2-3 years, were studied; 9 quantitative traits and 5 qualitative traits were measured on each doe. The doe's genomic DNA was extracted and amplified by using PCR with a panel of 10 ISSR microsatellite markers along with collecting phenotypic data from each animal. The results revealed the presence of two main clusters both genetically and morphologically: CI and CII where most of CI animals produced a lower quantity of milk compared to CII. The mean value for all quantitative traits, except barrel length, showed a superior significant difference between groups $(\mathrm{p} \leq 0.05)$. A positive correlation between the percentage of polymorphism, quantity of milk, ears and head color in both groups was observed. This attempt was to genetically characterize Lebanese Baladi population and to correlate its phenotype with its genotype.
\end{abstract}

Keywords: Baladi goat, genetic, genotype, ISSR, phenotype. https://doi.org/10.36899/JAPS.2021.2.0229

Published online October 03,2020

\section{INTRODUCTION}

Goats (Capra hircus) are among the oldest domesticated animals and play an important economic role in developing countries (Mello de Araújo et al., 2010; Khouri, 1997). Recently, the Mediterranean region comprises about $16 \%$ of the whole goat breeds and produces more than a quarter of the caprine milk production (FAO, 2014). In Lebanon, more than 6000 families are living from the income of goat herd products such as milk, meat and fur (MOA, 2009). This herd is represented by the local caprine population known as Baladi (95\%) and by the Damascus breed (Hajj, 1999; Nehme and Abi Saab, 2003). Baladi goat is of particular interest because of its ability to walk long distances and its good thermal regulation (Abi Saab et al., 2008; Silanikove and Koluman 2015). This population is known for its hardiness and its adaptation to various environmental conditions (Anwar et al., 2012). In the Eastern Mediterranean region, most goats are reared under extensive system. Pastoralism and vertical transhumance are the key source of feeds as well as commodities (Makarewicz et al., 2017). This system, despite its low cost, leads to an increase in energy expenditure and therefore affects the production negatively. Hence, understanding the relation between the phenotype and genotype would be beneficial in order to increase the production. Nowadays, few existing information regarding the genetic data on Baladi population is available; it remains imprecise since earlier studies were only based on morphological and biochemical markers.

The purpose of this study is to genetically characterize the diversity of the Lebanese Baladi population. This analysis, using genomic microsatellites inter-simple sequence repeat (ISSR) will be the major key in understanding the level of goat's genetic diversity in Lebanon. Revealing Baladi population genetic structure and its correlation with the associated phenotype will be an essential key for achieving many genetic improvements through genome-wide association and genomic selection studies.

\section{MATERIALS AND METHODS}

Site of study, meteorological data and animals used: This experiment was carried out during 2018, in two different regions of Lebanon: Deir El Ahmar $\left(34^{\circ} 07^{\prime} 52.4^{\prime \prime} \mathrm{N} \quad 36^{\circ} 06^{\prime} 41.8^{\prime \prime} \mathrm{E}\right)$ and Boksmaya $\left(34^{\circ} 15^{\prime} 05.1^{\prime \prime} \mathrm{N} 35^{\circ} 45^{\prime} 56.0^{\prime \prime} \mathrm{E}\right)$, located at $1450 \mathrm{~m}$ and $400 \mathrm{~m}$ respectively. The variation of the climatic conditions concerning the temperature $\left(\mathrm{T}\right.$ in $\left.{ }^{\circ} \mathrm{C}\right)$, the relative humidity ( $\mathrm{RH}$ in \%) as well as the temperature humidity index (THI) were registered by a meteo station belonging to the Lebanese Agricultural Research Institute (LARI).

Twenty-three does from Deir El Ahmar and twenty-four does from Boksmaya were used. They were 
between two to three years of age. Their weight fluctuated between $35.8 \mathrm{~kg}$ and $40.2 \mathrm{~kg}$. They were managed under extensive system and received $200 \mathrm{~g}$ of barley as supplements only during the period of poverty of pastures. The sampled animals were selected to represent the different morphotypes of Baladi goats in Lebanon as much as possible based on the available information of phenotypic characteristics. Throughout the experiment, does were free from any external or internal parasites.

A total of 9 quantitative traits and 5 qualitative traits were recorded. All traits were measured on each individual animal. Quantitative traits were the following: quantity of milk, which was measured once per day, in the evening after milking by using a graduated beaker, length of horns, length of ears, length of fur, bridge of nose, cannon bone, length from back, length from hip bone and length from point of shoulder. Each parameter was measured three times for more accuracy. Qualitative traits which were recorded included: color of the body, the head and the ears (black, white, gray, brown, and mixed), the presence or absence of goatees and wattles.

\section{Molecular characterization}

Inter-Simple Sequence Repeat (ISSR) technique: Inter simple sequence repeat (ISSR) was applied, as molecular fingerprinting technique via ten specific primers to get better understanding for Baladi goat, as described by Marzouk et al. (2016).

DNA Extraction and Preparation of the PCR master mix: Blood samples were collected into vacutainers with EDTA as anticoagulant. Samples were kept at $-20^{\circ} \mathrm{C}$ until use. Total DNA was extracted according to the manufacturer protocol of GenJet Genomic DNA Purification Kit (K0721/ Thermo fisher). In regards to the PCR master mix, DreamTaq PCR Master Mix (2X) was used also as manufacturer protocol (K1071, Thermo fisher. USA).

Inter-Simple Sequence Repeat (ISSR) amplification: Total genomic DNA was amplified through GeneAmp Polymerase Chain Reaction (PCR) system cycler. Ten specific ISSR primers (table 1) were used. PCR amplification protocol was carried out according to Simaei-Soltani et al., (2016) with some minor modifications. Polymerase chain reaction was performed in a $15 \mu \mathrm{L}$ final volume containing 1 unit Taq DNA polymerase, $1.5 \mu \mathrm{L}$ of $10 \times$ PCR buffer, $0.2 \mathrm{mM}$ dNTPs, $0.25 \mu \mathrm{M}$ of primer, $25 \mathrm{mM}$ of $\mathrm{MgCl} 2$ and 50-100 ng of genomic DNA. PCR was carried out in an initial denaturation at $94^{\circ} \mathrm{C}$ for $3 \mathrm{~min}$, followed by 35 cycles of 30 seconds for denaturation at $94^{\circ} \mathrm{C}, 45$ seconds for annealing at the temperature optimized for each primer and 90 seconds for extension at $72^{\circ} \mathrm{C}$, and a final extension step at $72^{\circ} \mathrm{C}$ for $7 \mathrm{~min}$. Then, $12 \mu \mathrm{L}$ of PCR products with $2 \mu \mathrm{L}$ of tracking dye was electrophoresed on a $1.2 \%$ non-denatured agarose gel and visualized over UV light after ethidium bromide staining to detect the amplification

Data analysis: Quantitative parameters measurements were averaged to obtain one measurement per animal. Averages were used in subsequent statistical analysis. Gel documentation system (Geldoc-It, UVP, England) was applied for genetic data analysis using TotalLab analysis software. ISSR amplified bands were scored for band presence (1) or absence (0) and a binary qualitative data matrix was constructed. The similarity values were used to generate a dendrogram via the un-weighted pair group method with arithmetic average (Rohlf, 1998). Phenotypic and molecular data were subjected to a multiple regression analysis. Molecular data were assumed as independent variable and morphological data as dependent variable respectively. In order to interpret the repartition of genetic variation at intra- population level, ANOVA analysis were conducted through calculation of molecular variance.

\section{RESULTS}

Morphological diversity: Cluster analysis of morphological and genetic traits, following the ward's linkage method, are presented in figure 1 and 2 respectively. Both dendrograms showed the presence of two main clusters: CI and CII. Based on morphological traits, these 2 clusters can be further subdivided into G1, G2, G3, G4 and G5 which include 4, 13, 8, 6 and 16 does respectively. Based on genetic traits, these 2 clusters can also be divided into 5 subgroups G1, G2, G3, G4 and G5 which include 10,10, 4, 10 and 12 does respectively. Table 2 displays the variability of the quantitative traits between the 5 groups. The mean values of all quantitative traits, except barrel length, showed a significant difference $(\mathrm{p} \leq 0.05)$ superior for G1 vs G2 vs G3 vs G4 vs G5 $(3.1 \mathrm{~kg} \pm 0.5$ vs $2.6 \mathrm{~kg} \pm 0.5$ vs $2.5 \mathrm{~kg} \pm 0.4$ vs $1.6 \mathrm{~kg} \pm$ 0.3 vs $2.3 \mathrm{~kg} \pm 0.6$ for milk quantity). Tables 3 and 4 showed the variability of the qualitative traits between the 5 groups. According to table 3, most goats were multicolored in coat, head and ear colors with G4 having the highest percentage for all three parameters; $67 \%, 83 \%$ and $83 \%$ for coat color, head color and ear color respectively. Table 4 displays the presence or absence of horns, barbiche and drops. All goats from G3 and G5 had horns and only $15 \%$ of G4 possessed it. All animals in G1 had barbiche whereas only $60 \%$ of G4 possess it. Half the goats in both G1, G3 and G4 had drop and only $20 \%$ and $25 \%$ in G2 and G5 respectively possessed it. Results of repartition of genetic variation at intra- population level, indicated a considerable genetic differentiation between individuals of the same population with a molecular variance of $25 \%$. 
Genetic diversity: The percentage of polymorphic bands are presented in table 5. All microsatellite markers used showed to be highly polymorphic for the molecular characterization of Baladi goats. The total number of amplified bands ranged from 68 to 199 bands per primer. The percentage of polymorphic bands (PPB) ranged between $29.4 \%$ and $85.7 \%$. The high PPB in most of the cases suggests these primers are suitable polymorphic markers to detect the genetic diversity. Table 6 shows the positive correlation between quantitative and qualitative traits and the percentage of polymorphism. Around $62 \%$ of the quantity of milk trait between individuals seems related to genetic factors. The greatest correlation was observed with the quantity of milk, the color of the head and of ears.

Table 1. Inter simple sequence repeat (ISSR) primers used to characterize Baladi goats.

\begin{tabular}{|c|c|c|c|}
\hline \multirow{11}{*}{ 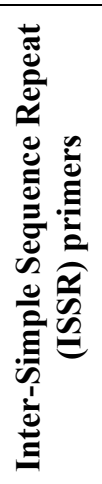 } & \multicolumn{2}{|c|}{ Sequences } & $\begin{array}{c}\text { Annealing } \\
\text { temperature }\left({ }^{\circ} \mathbf{C}\right)\end{array}$ \\
\hline & 1 & (ATG)6 & 43 \\
\hline & 2 & $(\mathrm{AG}) 8 \mathrm{G}$ & 52 \\
\hline & 3 & (GA)8C & 54 \\
\hline & 4 & (AC) $8 \mathrm{C}$ & 60 \\
\hline & 5 & (TC)8A & 50 \\
\hline & 6 & (AG)8T & 52 \\
\hline & 7 & (GT)8C & 56 \\
\hline & 8 & (CA)8G & 52 \\
\hline & 9 & (GAA)6 & 51 \\
\hline & 10 & (AG)8TT & 52 \\
\hline
\end{tabular}

Table 2. Variability of quantitative parameters between G1, G2, G3, G4 and G5, by hierarchical analysis.

\begin{tabular}{|c|c|c|c|c|c|}
\hline Group Parameter & G1 & G2 & G3 & G4 & G5 \\
\hline Quantity of milk & $3.1 \pm 0.5^{\mathrm{a}^{* *}, \mathrm{~b}^{* *}}$ & $2.6 \pm 0.5^{\mathrm{c}^{*}, \mathrm{~d}^{* *}, \mathrm{e}^{* *}}$ & $2.5 \pm 0.4^{\mathrm{f}^{* *}, \mathrm{~g} *}$ & $1.6 \pm 0.3^{\mathrm{a}^{* *}, \mathrm{c}^{*}, \mathrm{f}^{* *}}$ & $2.3 \pm 0.6^{\mathrm{b}^{* *}, \mathrm{~d}^{* *}, \mathrm{e}^{* *}, \mathrm{~g}^{*}}$ \\
\hline Length of horns & $8.5 \pm 6.2^{\mathrm{a}^{* *}}$ & $12.2 \pm 9.6^{\mathrm{b}^{* *}}$ & $13.3 \pm 2.5^{\mathrm{c}^{* *}}$ & $12.0 \pm 0.0^{\mathrm{d}^{* *}}$ & $30.7 \pm 8.1^{\mathrm{a}^{* *}, \mathrm{~b}^{* *}, \mathrm{c}^{* *}, \mathrm{~d}^{* *}}$ \\
\hline Length of ears & $19.3 \pm 3.2$ & $22.5 \pm 6.4^{\mathrm{a}^{*}}$ & $13.1 \pm 3.6^{\mathrm{a}^{*}, \mathrm{~b}^{*}}$ & $16.8 \pm 8.1$ & $22.3 \pm 6.5^{\mathrm{b}^{*}}$ \\
\hline Length of fur & $7.0 \pm 0.0^{\mathrm{a}^{* *}, \mathrm{~b}^{* *}}$ & $7.6 \pm 3.8^{\mathrm{c}^{* * *}, \mathrm{~d}^{* *}}$ & $5.7 \pm 2.7 \mathrm{e}^{* *}, \mathrm{f}^{* *}$ & $15.0 \pm 3.2^{\mathrm{a}^{* *}, \mathrm{c}^{* *}, \mathrm{f}^{* *}}$ & $14.2 \pm 2.6^{\mathrm{b}^{* *}, \mathrm{~d}^{* *}, \mathrm{e}^{* *}}$ \\
\hline Forehead and muzzle & $21.5 \pm 5.8$ & $19.1 \pm 5.2^{\mathrm{a}^{*}}$ & $22.7 \pm 5.3$ & $22 \pm 3.28$ & $23.7 \pm 2.4^{\mathrm{a}^{*}}$ \\
\hline Barrel length & $23.8 \pm 6.0$ & $22.6 \pm 7.0$ & $19.2 \pm 6.1$ & $26.5 \pm 6.9$ & $23.9 \pm 6.7$ \\
\hline Height wither & $64.2 \pm 15.7$ & $78.1 \pm 8.2^{\mathrm{a}^{* *}}$ & $56.9 \pm 13.7^{\mathrm{b}^{*}}$ & $70.8 \pm 6.5^{\mathrm{a}^{* *}}$ & $70.7 \pm 8.0^{\mathrm{b}^{*}}$ \\
\hline Past paste & $64.2 \pm 3.8^{\mathrm{a}^{* *}, \mathrm{~b}^{* *}, \mathrm{c}^{* *}, \mathrm{~d}^{* *}}$ & $39.5 \pm 5.0^{\mathrm{a}^{* *}, \mathrm{e}^{* *}, \mathrm{f}^{* *}}$ & $38.9 \pm 7.1^{b^{* *}, \mathrm{f}^{* *}, \mathrm{~g}^{* *}}$ & $23.8 \pm 4.5^{\mathrm{c}^{* *}, \mathrm{e}^{* *}, \mathrm{f}^{* *}}$ & $26.2 \pm 3.2^{\mathrm{d}^{* *}, \mathrm{~g}^{* *}}$ \\
\hline Posterior paste & $61.7 \pm 11.3^{\mathrm{a}^{* *}, \mathrm{~b}^{* *}, \mathrm{c}^{* *}, \mathrm{~d}^{* *}}$ & $44.0 \pm 8.1^{\mathrm{a}^{* *}, \mathrm{e}^{* *}, \mathrm{f}^{* *}}$ & $40.0 \pm 6.5^{\mathrm{b}^{* *}, \mathrm{f}^{* *}, \mathrm{~g}^{* *}}$ & $23.6 \pm 4.1^{\mathrm{c}^{* *}, \mathrm{e}^{* *}, \mathrm{f}^{* *}}$ & $27.1 \pm 2.1^{\mathrm{d}^{* *}, \mathrm{~g}^{* *}}$ \\
\hline
\end{tabular}

a.b. c. d. e. f. $g=$ means in the row with no common superscript letters differ $(\mathrm{P} \leq 0.05)$

Significant difference is represented by different $*(p \leq 0.05) * *(p \leq 0.01)$

Table 3. Percentage of coat, head and ear colors in G1, G2, G3, G4 and G5

\begin{tabular}{|c|c|c|c|c|}
\hline & Color & Coat & Head & Ears \\
\hline & Black & 25 & 0 & 0 \\
\hline & White & 25 & 25 & 25 \\
\hline \multirow[t]{5}{*}{ G1 } & Gray & 25 & 50 & 25 \\
\hline & Brown & 0 & 0 & 0 \\
\hline & Multicolor & 25 & 25 & 75 \\
\hline & Black & 8 & 8 & 31 \\
\hline & White & 8 & 31 & 8 \\
\hline \multirow[t]{5}{*}{ G2 } & Gray & 0 & 0 & 0 \\
\hline & Brown & 0 & 0 & 0 \\
\hline & Multicolor & 85 & 62 & 62 \\
\hline & Black & 13 & 13 & 25 \\
\hline & White & 38 & 25 & 25 \\
\hline \multirow[t]{3}{*}{ G3 } & Gray & 0 & 0 & 25 \\
\hline & Brown & 0 & 0 & 0 \\
\hline & Multicolor & 50 & 50 & 25 \\
\hline G4 & Black & 17 & 0 & 17 \\
\hline
\end{tabular}




\begin{tabular}{clccc}
\hline & White & 17 & 17 & 0 \\
& Gray & 0 & 0 & 0 \\
& Brown & 0 & 0 & 0 \\
Multicolor & 67 & 83 & 83 \\
& Black & 19 & 0 & 13 \\
& White & 31 & 13 & 0 \\
& Gray & 6 & 0 & 6 \\
& Brown & 0 & 13 & 75 \\
\hline
\end{tabular}

Table 4. Presence or absence of horns, barbiche and drop in different sub-groups.

\begin{tabular}{|c|c|c|c|c|c|c|c|c|c|c|}
\hline & \multicolumn{2}{|c|}{ G1 } & \multicolumn{2}{|c|}{ G2 } & \multicolumn{2}{|c|}{ G3 } & \multicolumn{2}{|c|}{ G4 } & \multicolumn{2}{|c|}{ G5 } \\
\hline & $\begin{array}{l}\ddot{U} \\
\tilde{D} \\
0 \\
0 \\
0\end{array}$ & 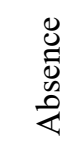 & $\begin{array}{l}\ddot{U} \\
\text { D. } \\
\ddot{D} \\
0\end{array}$ & 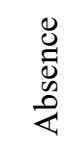 & 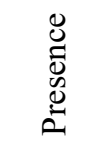 & 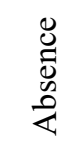 & $\begin{array}{l}\ddot{U} \\
\ddot{U} \\
0 \\
0 \\
0\end{array}$ & $\begin{array}{l}0 \\
0 \\
0 \\
0 \\
\text { \& }\end{array}$ & 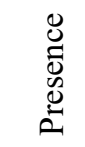 & 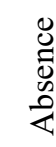 \\
\hline Horns & 75 & 25 & 70 & 30 & 100 & 0 & 15 & 85 & 100 & 0 \\
\hline Barbiche & 100 & 0 & 80 & 20 & 90 & 10 & 60 & 40 & 95 & 5 \\
\hline Drop & 50 & 50 & 20 & 80 & 50 & 50 & 50 & 50 & 25 & 75 \\
\hline
\end{tabular}

Table 5.Percentage of polymorphism by primer.

\begin{tabular}{cccc}
\hline & Total amplified bands & Polymorphic bands & Polymorphism percentage \\
\hline (ATG)6 & 125 & 97 & 76.6 \\
(AG)8G & 192 & 159 & 85.7 \\
(GA)8C & 136 & 41 & 29.4 \\
(AC)8C & 122 & 29 & 23.5 \\
(TC)8A & 199 & 155 & 77.7 \\
(AG)8T & 96 & 31 & 29.5 \\
(GT)8C & 119 & 73 & 59.8 \\
(CA)8G & 158 & 60 & 37.7 \\
(GAA)6 & 68 & 31 & 39.3 \\
(AG)8TT & 113 & 65 & 52.5 \\
\hline
\end{tabular}

Table 6. Positive correlation between quantitative traits, qualitative traits and percentage of polymorphism.

\begin{tabular}{ccccc}
\hline & $\begin{array}{c}\text { Quantity of } \\
\text { milk }\end{array}$ & $\begin{array}{c}\text { Average of } \\
\text { Polymorphism \% }\end{array}$ & Head color & Color of ears \\
\hline Quantity of milk & 1 & & & \\
Average of Polymorphism & 0.62 & 1 & 1 & 1 \\
Head color & 0.46 & 0.57 & 0.52 & 1 \\
Color of ears & 0.43 & 0.5 & & \\
\hline
\end{tabular}




\section{Dendrogram}

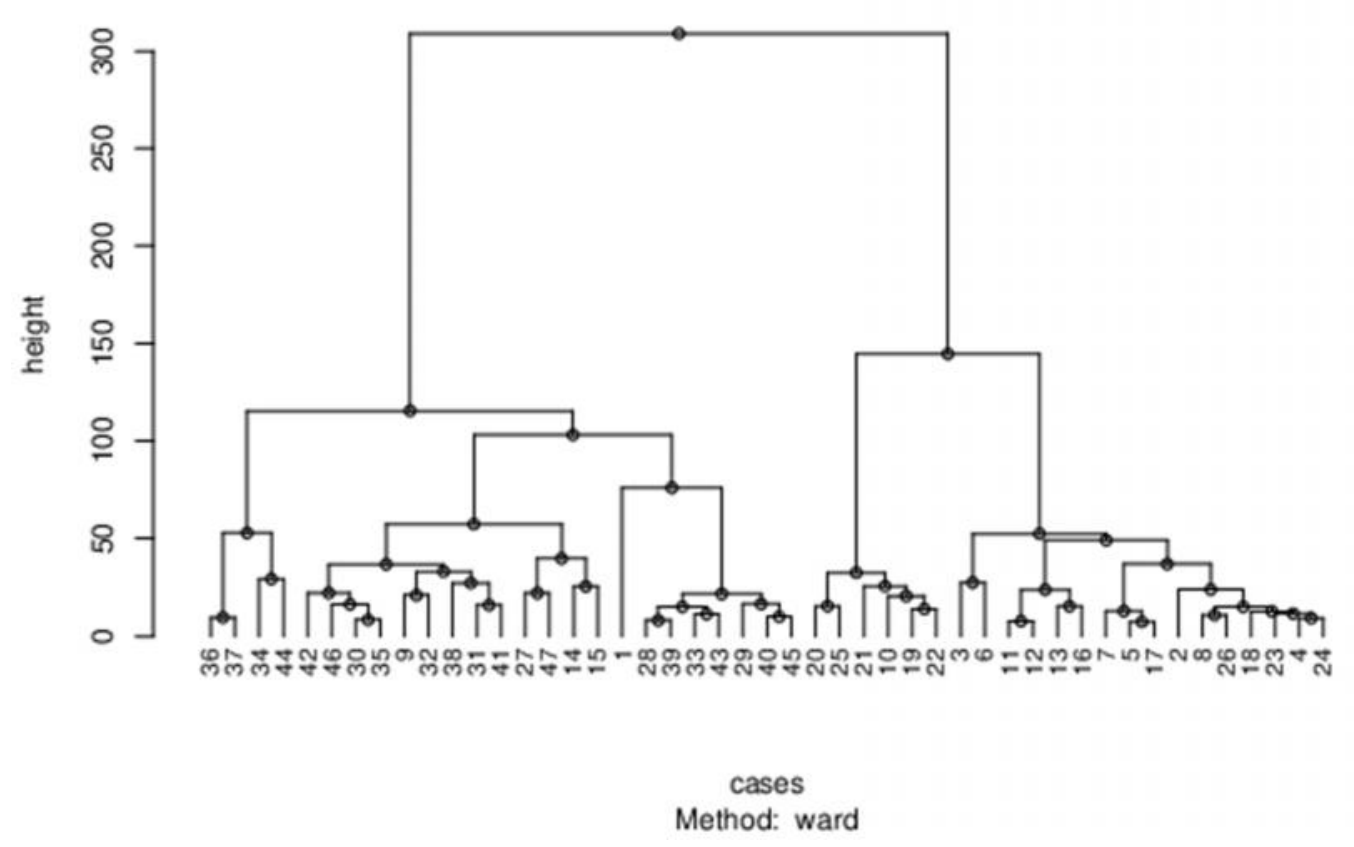

Figure 1: Dendrogram showing degree of similarities between 47 individuals of Lebanese Baladi goats obtained from the cluster analysis (Ward's linkage method) based on morphological traits.

\section{Dendrogram}

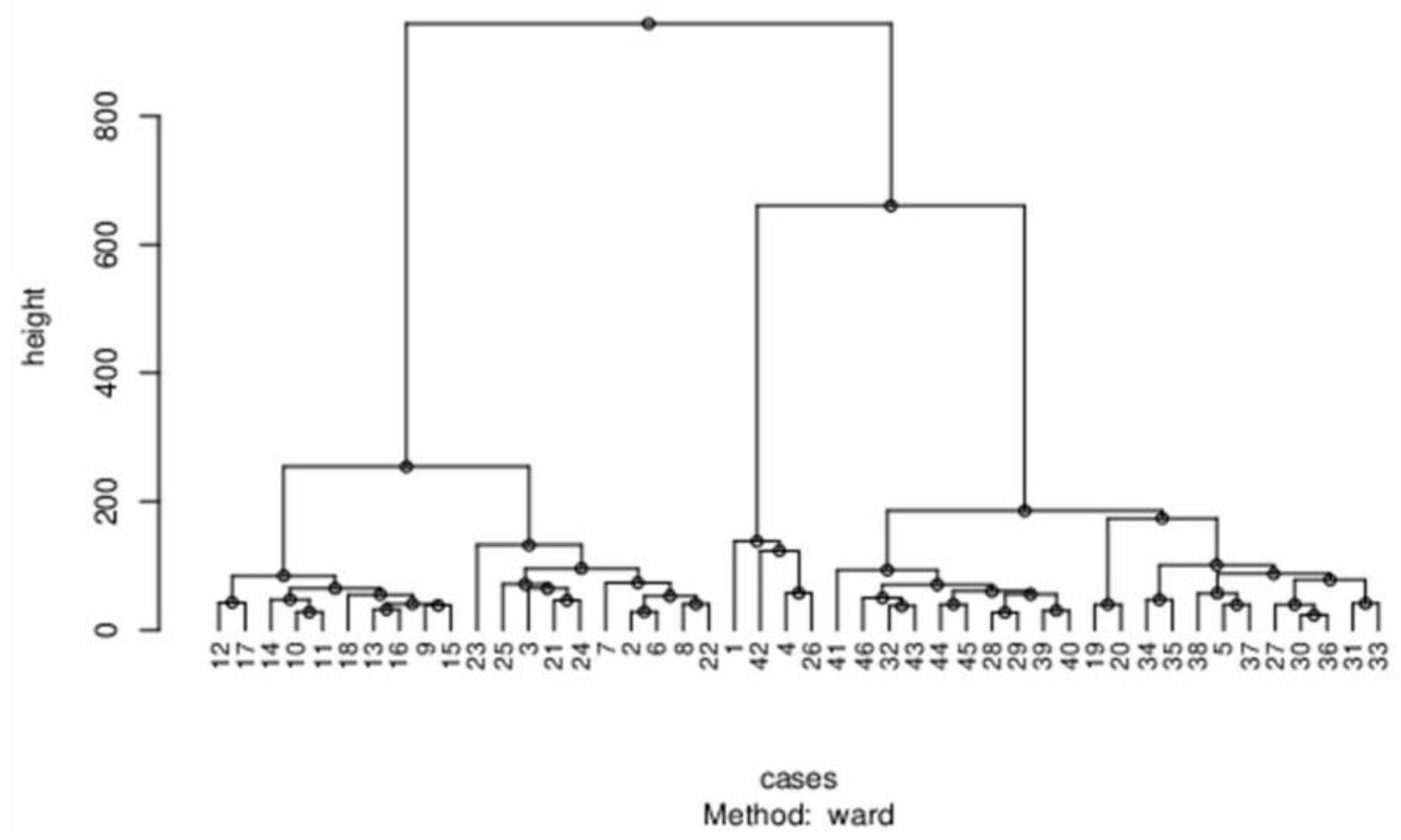

Figure 2: Dendrogram showing degree of similarities between 47 individuals of Lebanese Baladi goats obtained from the cluster analysis (Ward's linkage method) based on genetic traits. 


\section{DISCUSSION}

Genetic diversity is valuable. It is a recognized element and is needed for genetic improvement of all domestic animals. Loosing genetic diversity would lead to high levels of uniformity and an increase in the frequency of genetic defects. Ahlawat et al., (2013), stressed on the importance of improving the economic trait of goats such as reproductive trait. This experiment showed that Baladi goat population in Lebanon is actually divided into 2 major clusters. The latter can be divided into 5 groups which are morphologically and genetically distinct. These goat groups were well structured, and presented an important pool of genetic diversity and high level of mixture. Interbreed variability observed in this study might be due to individual variation or genetics. Similar studies have been done in Egypt on seven different goat breeds in order to assess their genetic diversity (Marzouk et al., 2016). Contrary to our results, it proved that individuals belonging to the same breed showed similarity and genetic variability was observed between breeds. This difference might be due to the fact that Baladi goat is actually made from two different breeds. Ganai and Yadav, (2007) also proved that the Indian goat breed possesses very high genetic variability. Moradi et al., (2014) used the ISSR markers in order to assess the genetic diversity of the Iranian Markhoz goat and its color types. In his study, four primers were designed out of which two were chosen based on their polymorphic properties and their number of bands. Results showed that genetic diversity of Markhoz goat was higher than Iranian Holstein cattle and less than Kermani sheep. Additionally, Nasr et al., (2016) proved that single nucleotide polymorphism (SNP) can also be used as hereditary markers due to their scattering among the genome and their high recurrence, supporting selection for significant economic traits. Michaillidou et al., (2019) looked for SNP, for downstream analysis, and found out that both Eghoria and Skopelos breeds display great level of diversity. In addition to this, in this current study, results of correlation analysis showed a significant relationship between the percentage of polymorphism and some quantitative and qualitative traits. Comparable experiments (Hykaj and Hoda, 2014) have studied this correlation by using a similar technique known as AFLP. Furthermore, these results are in accordance with Seligmann (2010) who stated that there is a positive correlation between genotype and phenotype. Zhou et al., (2015) indicated that the high genetic and phenotypic correlation for body weight traits, can be used for selection at an early age. This would improve breeding programs. Kominakis, (2003), stated that phenotypic correlation may be a substitute for genetic correlation when the latter are not available. Hence one can conclude that the herder can use the color of the head and the color of the ear as an indicator for the quantity of the milk.
From our knowledge, this is one of the first attempts to genetically characterize Lebanese mountain Baladi goats and to correlate its phenotype with its genotype. ISSR was successfully used in order to assess the genetic diversity and the level of polymorphism within this breed. All microsatellites which were used were highly polymorphic. It proved that the Lebanese mountain Baladi goat is not a single population but rather possesses high genetic variability. In the near future, these data must be benchmarked with an inter-population sampling and data analysis. This would help in the identification of other possible subpopulations. Furthermore, other phenotypic parameters, a bigger sample size and more molecular markers should also be taken into consideration in order to better characterize the different Baladi subpopulations.

\section{REFERENCES}

Abi Saab, S. (1997). Implications of high and low protein levels on puberty and sexual maturity of growing male goat kids. Small Rumin. Res. 25 (1) : $17-22$.

Abi Saab, S., E. Hajj, B. Abi Salloum. and E. Rahme (2008). Seasonal and altitudinal variations on adaptation, growth and testicular activity of Baladi goats with vertical transhumance in Eastern Mediterranean. Lebanese Sci. J. 9 (1): 99-110.

Agha, S. H. (2008). Genetic diversity in Egyptian and Italian goat breeds measured with microsatellite polymorphism. J Anim. Breed. Genet.125 (3): 194-200.

Ahlawat, S., Sharma, R. and Maitra, A. (2013). Screening of indigenous goats for prolificacy associated DNA markers of sheep. Gene, 517: 128-131.

Anwar, M. M., T. A. Ramadan, and T. A. Taha (2012). Serum metabolites, milk yield, and physiological responses during the first week after kidding in Anglo-Nubian, Angora, Baladi, and Damascus goats under subtropical conditions. J. Anim. Sci., 90: 4795-4806.

FAO (2014). Food and Agriculture Organization of the United Nations, Rome, Italy.

Ganai, N. A. and B. R. Yadav (2007). Genetic variation within and among three Indian breeds of goats using heterologous microsatellite markers. Anim. Biotech. 12: 121-136.

Hajj, E. (1999). Enquête sur l'élevage caprin au Liban. La Chèvre. 230 : 37-40.

Hosri, C. and N. El Khoury (2004). Valoriser le fromage de chèvre traditionnel « Darfiyeh » pour aider au développement de la région montagnarde nord libanaise. In : Dubeuf J. P. (ed). L'évolution des systèmes de production ovine et caprine : avenir 
des systèmes extensifs face aux changements de la société. Zaragoza: CIHEAM. 201-206.

Hykaj, G. and A. Hoda (2014). Genetic diversity of Albanian goat breeds estimated by molecular markers. Albanian J. Agri. Sci., (Special Edition):249-252.

Khouri, F. (1997). The Encyclopedia of Goat Breeds in the Arab Countries. Conservation of Biodiversity and Environments in the Arab Countries. The Arab Center for the Studies of Arid Zones and Dry Lands (ACSAD/AS/P 158/1996). Damascus, Syrian Arab Republic.

Kominakis, A. P. (2003). Phenotypic correlations as substitutes to genetic correlations in dairy sheep and goats. J Anim Breed Genet. 120 (4):269281.

Marzouk, K. M., I. S. Shaban, M. Y. Mohamed and I. Agag (2016). Genetic Diversity among Seven Goat Breeds Assessed by Inter Simple Sequence Repeats (ISSR). Egyptian J. Sheep Goat Sci., 11 (3) : 135-144.

Makarewicz, C. A.. B. S. Arbuckle and A. Oztan (2017). Vertical transhumance of sheep and goats identified by intra-tooth sequential carbon $(\delta 13 \mathrm{C})$ and oxygen $(\delta 180)$ isotopic analyses: Evidence from Chalcolithic Köşk Höyük, central Turkey. J. Arch. Sci., 86: 68-80.

Mello de Araújo, A., S. E. Facioni Guimarães, C. S. F. Pereira, P. S. Lopes, M. T. Rodrigues and T. M. M. Machado (2010). Paternity in Brazilian goats with DNA microsatellites. R. Bras. Zootec. 5:1011-1014.

Michailidou, S., G. Tsangaris, A. Tzora, I. Skoufos, G. Banos, A. Argiriou and G. Arsenos (2019). Analysis of genome-wide DNA arrays reveals the genomic population structure and diversity in autochthonous Greek goat breeds. PloS, One, 12;14(12):e0226179. doi: 10.1371/ journal. pone. 0226179 .

MOA, Ministry Of Agriculture (2009). L'Agriculture au Liban en 2008-2009. Projet de recensement agricole général. Ministère de l'Agriculture, Directorat des Recherches et de la Coordination / FAO.

Moradi, M. H., J. Rostamzadh, A. Rashidi, K. Vahabi and H. Farahman (2014). Analysis of genetic diversity in Iranian mohair goat and its color types using Inter Simple Sequence Repeat (ISSR) markers. Agri. Commun. 2 (1): 55-62.

Nasr, M. A. F., A. Awad and I. E. El Araby (2016). Associations of leptin and pituitary-specific transcription factor genes polymorphisms with reproduction and production traits in dairy buffalo. Reprod. Domest. Anim., 51 : 597-603.

Nehme, M. and S. Abi Saab (2003). Effet des enveloppes de sésame et des brisures de lentille sur la production laitière des chèvres Baladi et Chami. CEDLUSEK, Annales de Recherche Scientifique. 4 : 233- 247.

Rohlf, F. J. (1998). NTSYSpc-Numerical taxonomy and multivariate analysis system (Version 2.0). User Guide. Applied Biostatistics INC. New York.

Seligmann, H. (2010). Positive correlations between molecular and morphological rates of evolution. Small Rumin. Res. 264 (3): 799-807.

Silanikove N. and N. Koluman (2015) Impact of climate change on the dairy industry in temperate zones: predications on the overall negative impact and on the positive role of dairy goats in adaptation to earth warming. Small Rumin. Res., 123: $27-$ 34

Simaei-Soltani, L., A. Abdolmohammadi, A. Zebarjadi and S. Foroutanifar (2016). Genetic diversity and distance of Iranian goat breeds (Markhoz, Mahabadi and Lori) compared to the Beetal breed using inter-simple sequence repeat (ISSR) markers. Arch. Anim. Breed., 59 (4) : 477.

Srour, G., M. Marie and S. Abi Saab (2004). Performances productives des élevages caprins et ovins au Liban. Opt. Méditerr. Série A, No. 70, 193-202. 